\title{
Drug assessment by a Pharmacy and Therapeutics committee: from drug selection criteria to use in clinical practice
}

This article was published in the following Dove Press journal:

Therapeutics and Clinical Risk Management

9 July 2014

Number of times this article has been viewed

\author{
Ana Lozano-Blázquez' \\ Cecilia Calvo-Pita ${ }^{2}$ \\ Mónica Carbajales-Álvarez' \\ Patricio Suárez-Gil ${ }^{3}$ \\ Fernando Martínez- \\ Martínez ${ }^{4}$ \\ Miguel Ángel Calleja- \\ Hernández ${ }^{5}$ \\ 'Pharmacy Department, Hospital \\ de Cabueñes, Gijón, Spain; \\ ${ }^{2}$ Pharmacy Department, Primary \\ Health Care, Servicio Madrileño \\ de Salud, Dirección Asistencial \\ Oeste, Madrid, Spain; ${ }^{3}$ Research \\ Unit Área V, Hospital de Cabueñes, \\ Gijón, Spain; ${ }^{4}$ Responsable del \\ Grupo de Investigación en Atención \\ Farmacéutica, Universidad de \\ Granada, ${ }^{5}$ UGC Provincial de Farmacia \\ de Granada Instituto de Biomedicina \\ de Granada, Hospital Virgen de las \\ Nieves, Granada, Spain
}

Correspondence: Ana Lozano Blázquez Pharmacy Department, Hospital de Cabueñes, Camino de los Prados 395, 33203 Gijón, Asturias, Spain

$\mathrm{Tel}+34985$ I 8018

Fax +34985I85032

Email analozanob@icloud.com
Background: In Spain, hospital medicines are assessed and selected by local Pharmacy and Therapeutics committees (PTCs). Of all the drugs assessed, cancer drugs are particularly important because of their budgetary impact and the sometimes arguable added value with respect to existing alternatives. This study analyzed the PTC drug selection process and the main objective was to evaluate the degree of compliance of prescriptions for oncology drugs with their criteria for use.

Methods: This was a retrospective observational study (May 2007 to April 2010) of PTCassessed drugs. The variables measured to describe the committee's activity were number of drugs assessed per year and number of drugs included in any of these settings: without restrictions, with criteria for use, and not included in formulary. These drugs were also analyzed by therapeutic group. To assess the degree of compliance of prescriptions, a score was calculated to determine whether prescriptions for bevacizumab, cetuximab, trastuzumab, and bortezomib were issued in accordance with PTC drug use criteria.

Results: The PTC received requests for inclusion of 40 drugs, of which 32 were included in the hospital formulary $(80.0 \%)$. Criteria for use were established for $28(87.5 \%)$ of the drugs included. In total, 293 patients were treated with the four cancer drugs in eight different therapeutic indications. The average prescription compliance scores were as follows: bevacizumab, $83 \%$ for metastatic colorectal cancer, $100 \%$ for metastatic breast cancer, and $82.3 \%$ for nonsmall-cell lung cancer; cetuximab, 62.0\% for colorectal cancer and 50\% for head and neck cancer; trastuzumab, $95.1 \%$ for early breast cancer and $82.4 \%$ for metastatic breast cancer; and bortezomib, $63.7 \%$ for multiple myeloma.

Conclusion: The degree of compliance with criteria for use of cancer drugs was reasonably high. PTC functions need to be changed so that they can carry out more innovative tasks, such as monitoring conditions for drug use.

Keywords: decision-making, drug selection, drug utilization, formulary, neoplasm, Pharmacy and Therapeutics committee

\section{Introduction}

The ongoing inclusion of new medications in hospital formularies is a key factor explaining the increase in health care spending; ${ }^{1,2}$ however, new medications do not always result in better health outcomes, ${ }^{3}$ with very few actually offering significant advantages over existing therapies in terms of efficacy and safety. For example, a study published in the French independent journal Prescrire International found that in the 5 years leading up to 2012, no new drugs licensed represented a significant advance for patients, and of 82 new drugs evaluated in 2012, only one represented a real advance and three offered an advantage. ${ }^{4}$ 
In the European Union, the procedure for authorizing the sale of new drugs does not require a comparison with standard treatments, so companies need only to prove that the risk-benefit balance of a new drug is favorable. ${ }^{5}$ Further, the procedure does not include a review of a drug's costeffectiveness or place in therapy. ${ }^{6}$

It is therefore necessary to carry out these analyses in an additional study. Most of the drugs available in Spain are funded by the public health service and there is no national government agency, such as the National Institute for Health and Care Excellence in the UK, which carries out a centralized evaluation and makes decisions about funding. ${ }^{7}$

The Spanish National Health Service has a decentralized structure whereby autonomous regions make their own decisions about health care spending and manage their budgets through their regional ministries of health. There are centers that evaluate new drugs, but they merely provide recommendations, which hospitals and prescribers are in no way obliged to follow.

So neither the national nor the regional health ministries set out shared guidelines to rationalize the use of medicines in the Spanish National Health Service based on criteria relating to effectiveness, appropriate use, and efficiency. Drugs are therefore assessed and selected locally. In recent years, regional health ministries have published new legislation to carry out baseline assessments for their regions, and some of them have established centralized PTCs that take some decisions mandatory for the whole region. Also, the Ministry of Health is currently in the process of conducting a cooperative national initiative project assessing comparative efficacy and safety and introducing use criteria for new drugs or existing drugs seeking approval for new indications.

Drugs used in hospitals (those administered to inpatients and outpatients attending the hospital for drug administration, and drugs that can only be dispensed by the hospital pharmacy service) are assessed by Pharmacy and Therapeutics committees (PTCs). These committees select the drugs to be used, generally taking into account pharmacoeconomic criteria and the relative efficiency of drugs compared with the alternatives available. The drugs that are selected are added to the formulary for each hospital. ${ }^{8}$

Once a drug has been selected, the PTC may establish conditions for its use so that the drug is only used in subgroups of patients where it will have clinically significant benefits and where the cost has been taken into account. Use of the drug must then be monitored to ensure that it meets the established criteria.
Of all the drugs assessed by PTCs, cancer drugs are particularly important because of their budgetary impact ${ }^{9,10}$ and their sometimes arguable added value with respect to existing alternatives, which is measured in terms of improved rates of survival or quality of life. ${ }^{11}$

To date, no studies have been published that monitor the real conditions of use of oncology drugs in Spanish National Health Service hospitals or that ascertain whether they are used in accordance with the PTC criteria set out by the hospital.

The aims of this study were to analyze the selection of new drugs by the PTC of a large secondary care hospital in Spain and to assess the degree to which the cancer drugs included in the hospital's formulary were used in accordance with the criteria for use set out by the PTC (compliance).

\section{Materials and methods Study design and setting}

A retrospective observational longitudinal study was carried out between May 1, 2007 and April 30, 2010 in the setting of Cabueñes Hospital, a Spanish National Health Service general secondary care hospital. The hospital serves a population of 303,038 in the Spanish region of Asturias. Oncology treatments for the whole area are administered at this hospital. The PTC of Cabueñes Hospital was created in 1974. It is a multidisciplinary committee made up of physicians, pharmacists, and nurses, as well as members of the hospital's management team. At the request of clinicians, the PTC assesses drugs for inclusion in the hospital formulary using the methodology proposed by the Group for Innovation, Assessment, Standardization and Research in the Selection of Drugs (GENESIS) of the Spanish Society of Hospital Pharmacy. ${ }^{12}$ The PTC can make one of three decisions for each drug: not included, included without criteria for use, and included with criteria for use.

\section{Drug selection by the PTC}

The study examined the selection of all new drugs assessed by the PTC during the study period. Drugs were selected for inclusion in the study by consulting the minutes of the PTC meetings.

Two main variables were collected in order to evaluate the selection activities of the PTC, ie, number of drugs assessed per year and number of drugs included in any of these settings: without restrictions, with criteria for use, and not included in formulary. The drugs were also analyzed by therapeutic group. 


\section{Compliance with drug inclusion criteria}

All oncology drugs approved by the PTC were included in the study. The drugs were bevacizumab, cetuximab, trastuzumab, and bortezomib, and their use was assessed from the time each one was approved by the PTC (bevacizumab May 20, 2008; cetuximab March 18, 2008; trastuzumab February 19, 2008; and bortezomib July 17, 2007).

Patients treated with any of the four cancer drugs (bevacizumab, cetuximab, trastuzumab, and bortezomib) were identified by consulting the pharmacy service database for the prescription, validation, and preparation of cytostatic drugs. Any other information required was retrieved from patients' notes. Patients taking part in a clinical trial and those taking any of the drugs for an off-label purpose as current national regulations lay down or for indications other than the treatment of cancer were excluded from the study. When a patient had used a drug for two different episodes, he or she was considered to be two respective patients. Identifying information was removed from patient records to maintain confidentiality; thus, approved of an investigational review board was not required.

In order to assess the degree to which prescriptions complied with the criteria for use stipulated by the PTC, the actual conditions under which each drug was being used were compared with the PTC's criteria for use. Compliance was analyzed based on a series of variables for each drug: diagnosis (tumor location) and compliance with criteria for use in terms of stage of the disease, life expectancy, treatment regimen (in combination with other drugs), line of treatment (preferred order for treatment options available), previous treatments, duration of treatment, and presence of certain gene mutations. When a drug was not used for the approved diagnosis (used off-label without asking for permission to use it, or for an indication not approved by the PTC), the rest of the variables were not assessed.

For each of the four drugs and for each of the clinical indications, a score was calculated using previous criteriafor-use variables. Each criterion had the same weighting and could be assigned one of two values: yes $(=1)$ or no $(=0)$. The final score for each drug and clinical indication was determined by calculating the sum of the scores for the criteria-for-use variables, expressed as a percentage (Table 1). This score represented compliance with the PTC criteria for use. This scoring system has been previously used by García Robredo et al. ${ }^{13}$ The number and percentage of patients meeting all of the criteria were calculated for each drug and indication.

\section{Statistical analysis}

Data on drug selection by the PTC were summarized in a frequency and percentage table. In order to assess the degree of compliance for each drug and indication, the average compliance percentage was calculated for each criterion for the group of patients treated in each case. The percentage of patients meeting all of the criteria for each drug and indication was calculated. The $95 \%$ confidence interval (CI) was computed. Both of these summarized measures were illustrated in bar graphs. The analysis was carried out and graphs were created using statistics program $\mathrm{R}$ (version 3.0.1, R Foundation for Statistical Computing, Vienna, Austria). ${ }^{14}$

\section{Results \\ Drug selection by the PTC}

Between May 2007 and April 2010, the PTC received requests for inclusion of 40 drugs in the hospital formulary (17 in the first year, eleven in the second, and 12 in the third), of which 32 were included $(80.0 \%)$. Criteria for use were established for $28(87.5 \%)$ of the drugs included. The four drugs included without criteria for use were assessed during the first year of the study.

By therapeutic group, the highest percentages of requests were for the Anatomical Therapeutic Chemical classification system $^{15}$ group L (antineoplastic and immunomodulation agents), with seven requests, and group J (anti-infective agents for systemic use), also with seven requests, followed by group $\mathrm{M}$ (musculoskeletal system), with five requests. Of the eight drugs not included in the formulary, four were in group M. All of the drugs in groups L and $\mathrm{J}$ were included with criteria for use (Table 2).

\section{Compliance with drug use}

The baseline characteristics of all patients are shown in Table 3. The degree of compliance for the four drugs with criteria for use defined by the PTC is described in Figure 1.

\section{Bevacizumab}

Bevacizumab was used in 114 patients. For 112 (98.2\%), it was used for the following PTC-approved indications: colorectal cancer in 57 patients $(50.0 \%)$, breast cancer in seven patients (6.1\%), and lung cancer in 48 patients (42.1\%). It was also used in two patients with renal cancer, an indication that is approved in the drug's summary of product characteristics but was not approved by the PTC.

All of the patients who were prescribed bevacizumab for metastatic colorectal cancer $(n=57)$ were assumed to have a life expectancy of more than 3 months. In nine patients, it was not 
Table I Indicator calculations

\begin{tabular}{|c|c|c|c|c|c|c|}
\hline Drug and indications & Criteria for use $^{a}$ & & & & & \\
\hline \multicolumn{7}{|l|}{ Bevacizumab } \\
\hline Metastatic colorectal & $\mathrm{Cl} . \mathrm{I}$ & $C 2.1$ & C3.I & & & \\
\hline cancer & Life expectancy $>3$ months ${ }^{b}$ & XELOX + bevacizumab & First-line & & & \\
\hline \multirow[t]{2}{*}{ Metastatic breast cancer } & $\mathrm{Cl} .2$ & $\mathrm{C} 2.2$ & C3.2 & C4.2 & & \\
\hline & No brain metastasis & $\begin{array}{l}\text { HER2-negative or } \\
\text { prior treatment with } \\
\text { trastuzumab }\end{array}$ & First-line & In combination & & \\
\hline Non-small-cell lung & $\mathrm{Cl} .3$ & $\mathrm{C} 2.3$ & C3.3 & C4.3 & C5.3 & C6.3 \\
\hline cancer & No squamous cells & Stage IIIB-IV & $\begin{array}{l}\text { No brain } \\
\text { metastasis }\end{array}$ & $\begin{array}{l}\text { Cisplatin }+ \\
\text { gemcitabine }+ \\
\text { bevacizumab }\end{array}$ & First-line & No hemoptysis \\
\hline \multicolumn{7}{|l|}{ Cetuximab } \\
\hline \multirow[t]{2}{*}{ Colorectal cancer } & $\mathrm{Cl} .4$ & $\mathrm{C} 2.4$ & C3.4 & C4.4 & & \\
\hline & Metastasis & EGFR expression & $\begin{array}{l}\text { Prior treatment } \\
\text { with oxaliplatin } \\
\text { or irinotecan }\end{array}$ & $\begin{array}{l}\text { In combination } \\
\text { with irinotecan }\end{array}$ & & \\
\hline Locally advanced head & $\mathrm{Cl} .5$ & $\mathrm{C} 2.5$ & & & & \\
\hline and neck cancer & Concomitant radiotherapy & $\begin{array}{l}\text { Not eligible for } \\
\text { treatment with cisplatin }^{c}\end{array}$ & & & & \\
\hline \multicolumn{7}{|l|}{ Trastuzumab } \\
\hline \multirow[t]{2}{*}{ Early breast cancer } & $\mathrm{Cl} .6$ & $\mathrm{C} 2.6$ & C3.6 & C4.6 & & \\
\hline & HER2 3+ & $\begin{array}{l}\text { After: surgery, adjuvant } \\
\text { or neoadjuvant } \\
\text { chemotherapy or } \\
\text { radiotherapy }\end{array}$ & $\begin{array}{l}\text { Carboplatin + } \\
\text { docetaxel }+ \\
\text { trastuzumab }\end{array}$ & $\begin{array}{l}\text { Treatment } \\
\text { duration I year }\end{array}$ & & \\
\hline \multirow[t]{2}{*}{ Metastatic breast cancer } & $\mathrm{Cl} .7$ & $\mathrm{C} 2.7$ & & & & \\
\hline & HER2 3+ & $\begin{array}{l}\text { Monotherapy, with } \\
\text { docetaxel or paclitaxel } \\
\text { or aromatase inhibitor }\end{array}$ & & & & \\
\hline \multicolumn{7}{|l|}{ Bortezomib } \\
\hline \multirow[t]{2}{*}{ Multiple myeloma } & $\mathrm{Cl} .8$ & $\mathrm{C} 2.8$ & & & & \\
\hline & Relapsing or refractory & Prior treatment & & & & \\
\hline
\end{tabular}

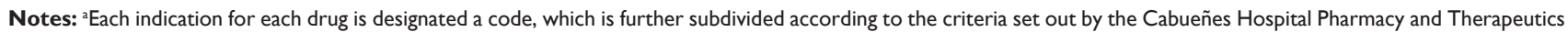
Committee. For each criterion, a score (yes $=l$; no $=0$ ) is given; scores are totaled to calculate the compliance with Pharmacy and Therapeutics committee criteria; ${ }^{\text {b Karnofsky }}$ score $\geq 50^{33}$ was used to determine life expectancy $>3$ months; 'patients who had a history of renal failure, hearing problems, or cardiovascular disease were considered ineligible for treatment with cisplatin.

Abbreviations: EGFR, epidermal growth factor receptor; HER2, human epidermal growth factor receptor 2; XELOX, capecitabine + oxaliplatin.

used concomitantly with capecitabine + oxaliplatin, and in 20 it was not used as a first-line treatment, so the average compliance score for this indication was $83 \%$ (95\% CI, 76.4\%-89.5\%). In the case of metastatic breast cancer, bevacizumab met all of the criteria for use and scored $100 \%$ for compliance. The degree of compliance in non-small-cell lung cancer was $82.3 \%$ (95\% CI, $78.4 \%-85.5 \%$ ) because, although in all cases it was prescribed to patients without hemoptysis and with non-squamous cancer and to just one patient with brain metastasis, in nine patients it was not used as a first-line treatment, in eleven it was used in stages earlier than those approved, and in 30 of the 48 patients it was used in a chemotherapy regimen other than cisplatin + gemcitabine.

\section{Cetuximab}

During the study period, 35 patients started treatment with cetuximab, of whom 25 (71.4\%) had colorectal cancer and ten $(28.6 \%)$ had head and neck cancer. Therefore, $100 \%$ of prescriptions for cetuximab were for diseases included in the criteria for use set out by the PTC.

The compliance score for colorectal cancer was $62 \%$ (95\% CI, 55.6\%-68.4\%). None of the patients with this type of cancer underwent epidermal growth factor receptor (EGFR) expression testing, all but two had metastases, and all but two had previously undergone chemotherapy with oxaliplatin or irinotecan. Cetuximab was administered in combination with irinotecan in 16 of the 25 patients.

In the case of head and neck cancer, only one of the ten patients was not taking cetuximab concomitantly with radiotherapy. All but one of the patients could have undergone treatment with cisplatin, but instead received cetuximab in combination with paclitaxel; this reduced the compliance score to $50 \%$ (95\% CI, 35.4\%-64.6\%). 
Table 2 Drugs requested for inclusion in hospital formulary

\begin{tabular}{|c|c|c|c|}
\hline \multirow[t]{4}{*}{ Year } & \multicolumn{3}{|l|}{ Drug (therapeutic group ${ }^{\mathrm{a}}$ ) } \\
\hline & \multirow{3}{*}{$\begin{array}{l}\text { Not included } \\
n=8(20 \%)\end{array}$} & \multirow{2}{*}{\multicolumn{2}{|c|}{$\begin{array}{l}\text { Included } \\
\mathrm{n}=32(80.0 \%)\end{array}$}} \\
\hline & & & \\
\hline & & $\begin{array}{l}\text { With criteria for use } \\
\mathrm{n}=28(87.5 \%)\end{array}$ & $\begin{array}{l}\text { Without criteria for use } \\
\mathrm{n}=4(12.5 \%)\end{array}$ \\
\hline \multirow[t]{10}{*}{ May 2007 to April 2008} & Eplerenone (C03DA) & Glutamine (B05XB) & Clonidine (C02AC) \\
\hline & Botulinum toxin type B (M03AX) & Bortezomib (LOIXX) ${ }^{b}$ & Levetiracetam (N03AX) \\
\hline & Bemiparin (BOIAB) & Entecavir (J05AF) & Olanzapine (N05AH) \\
\hline & & Aprepitant (A04AD) & Ranibizumab (SOILA) \\
\hline & & Gadobutrol (V08CA) & \\
\hline & & Emtricitabine/tenofovir (J05AR) & \\
\hline & & Trastuzumab (LOIXC) ${ }^{\mathrm{b}}$ & \\
\hline & & Cetuximab (LOIXC) $)^{\mathrm{b}}$ & \\
\hline & & Eptacog alfa (B02BD) & \\
\hline & & Bevacizumab (LOIXC) ${ }^{\mathrm{b}}$ & \\
\hline \multirow[t]{9}{*}{ May 2008 to April 2009} & Ibandronic acid (M05BA) & Fosfomycin-trometamol (J0IXX) & \\
\hline & $\begin{array}{l}\text { Insulin analogs (aspart, glulisine and } \\
\text { detemir) (AIOA) }\end{array}$ & Chlorthalidone (C03BA) & \\
\hline & & Esmolol (C07AB) & \\
\hline & & Nitrous oxide/oxygen (NOIAX) & \\
\hline & & Linezolid (J0IXX) & \\
\hline & & Pegfilgrastim (L03AA) & \\
\hline & & Abatacept (L04AA) & \\
\hline & & Emtricitabine/tenofovir/efavirenz (J05AR) & \\
\hline & & Zoledronic acid-osteoporosis (M05BA) & \\
\hline \multirow[t]{9}{*}{ May 2009 to April 2010} & Levobupivacaine (NOIBB) & Natalizumab (L04AA) & \\
\hline & Purified botulinum toxin type A (M03AX) & Sulpur hexafluoride (V08DA) & \\
\hline & Zoledronic acid-bone metastases (M05BA) & Thyrotropin alfa (V04CJ) & \\
\hline & & Fosamprenavir (J05AE) & \\
\hline & & Voriconazole (J02AC) & \\
\hline & & Caspofungin (J02AX) & \\
\hline & & Mifepristone (G03XB) & \\
\hline & & Misoprostol (G02AD) & \\
\hline & & Procainamide (COIBA) & \\
\hline
\end{tabular}

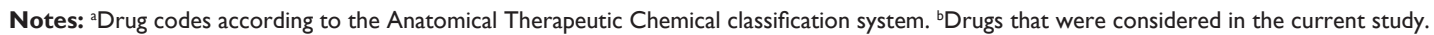

\section{Trastuzumab}

Trastuzumab was used in 80 patients, but in two cases $(2.5 \%)$ the drug was used in nonapproved indications (stomach cancer and sweat gland cancer). The highest compliance score was for early breast cancer (95.1\%; 95\% CI, 92.1\%-98.2\%), because all of the criteria were met in all but eight patients who were on a regimen other than carboplatin + docetaxel + trastuzumab. Thirteen of the 37 patients with metastatic breast cancer were using trastuzumab in an unapproved chemotherapy regimen, resulting in a final compliance score for this indication of $82.4 \%$ (95\% CI, $74.3 \%-90.2 \%$ ).

\section{Bortezomib}

Bortezomib was used in 64 patients, but in two cases the drug was used for indications not approved by the PTC (mantle cell lymphoma and Waldenström's macroglobulinemia). Of the 62 patients undergoing treatment with bortezomib for multiple myeloma, it was used as a second-line or subsequent treatment in only 39 . In one of these patients, the later lines of treatment were not administered as a result of relapse or resistance but because of side effects, which meant the previous line had to be stopped. The final compliance score was therefore $63.7 \%$ (95\% CI, 51.6\%-75.7\%).

\section{Discussion}

The percentage of requested drugs that were included in the hospital formulary was similar to that found in previous national studies. ${ }^{16}$ This may be because of the tendency in Spain to standardize assessment methodologies, as encouraged by the Group for Innovation, Assessment, Standardization and Research in the Selection of Drugs. ${ }^{17}$ This means that different hospitals and PTCs may use similar selection systems and procedures.

The number of drugs assessed decreased in the second and third years of the study because the PTC was not operational in 2006. This meant that extra effort was made in 2007 to assess the drugs requested during the committee's period of inactivity. All of the oncologic drugs were assessed during 
Table 3 Patient baseline characteristics

\begin{tabular}{|c|c|c|c|c|c|c|c|c|}
\hline \multirow[t]{2}{*}{$\bar{n}$} & \multirow{2}{*}{$\begin{array}{l}\text { Bortezomib } \\
62 \\
\text { Multiple } \\
\text { myeloma }\end{array}$} & \multicolumn{2}{|c|}{$\begin{array}{l}\text { Cetuximab } \\
35\end{array}$} & \multicolumn{2}{|c|}{$\begin{array}{l}\text { Trastuzumab } \\
78\end{array}$} & \multicolumn{3}{|c|}{$\begin{array}{l}\text { Bevacizumab } \\
112\end{array}$} \\
\hline & & $\begin{array}{l}\text { Head } \\
\text { and neck } \\
\text { cancer }\end{array}$ & $\begin{array}{l}\text { Colorectal } \\
\text { cancer }\end{array}$ & $\begin{array}{l}\text { Early } \\
\text { breast } \\
\text { cancer }\end{array}$ & $\begin{array}{l}\text { Metastatic } \\
\text { breast } \\
\text { cancer }\end{array}$ & $\begin{array}{l}\text { Non-small- } \\
\text { cell lung } \\
\text { cancer }\end{array}$ & $\begin{array}{l}\text { Metastatic } \\
\text { colorectal } \\
\text { cancer }\end{array}$ & $\begin{array}{l}\text { Metastatic } \\
\text { breast } \\
\text { cancer }\end{array}$ \\
\hline Patients n (\%) & $62(21.6)$ & $10(3.5)$ & $25(8.7)$ & $4 \mid(\mid 4.3)$ & 37 (12.9) & 48 (16.7) & 57 (19.9) & $7(2.4)$ \\
\hline Age mean (SD) & $67.7(8.9)$ & $57.3(9.3)$ & $61.9(12.2)$ & $55.7(\mathrm{II} .1)$ & $60.3(12.6)$ & $60.8(8.0)$ & $62.6(9.6)$ & $60.4(12.4)$ \\
\hline \multicolumn{9}{|l|}{ Sex } \\
\hline Male n (\%) & 37 (59.7) & $8(80.0)$ & $17(68.0)$ & $0(0.0)$ & I (2.7) & 39 (8I.2) & $33(57.9)$ & $0(0.0)$ \\
\hline Female n (\%) & $25(40.3)$ & $2(20.0)$ & $8(32.0)$ & $41(100.0)$ & $36(97.3)$ & $9(18.8)$ & $24(42.1)$ & $7(100)$ \\
\hline \multicolumn{9}{|l|}{ Stage: $\mathbf{n}$} \\
\hline I & & 1 & & 10 & & & & \\
\hline IB & & & & & & I & & \\
\hline II & & I & & & & & & \\
\hline IIA & & & & II & & & & \\
\hline IIB & & & & 5 & & I & & I \\
\hline III & & 3 & 2 & & & & I & \\
\hline IIIA & & & & II & & 9 & I & \\
\hline IIIB & & & & 4 & & 11 & I & \\
\hline IV & & 5 & 23 & & 37 & 26 & 53 & 6 \\
\hline Unknown & 13 & & & & & & I & \\
\hline ISS-I & 10 & & & & & & & \\
\hline ISS-II & 17 & & & & & & & \\
\hline ISS-III & 22 & & & & & & & \\
\hline \multicolumn{9}{|l|}{ PS (ECOG) $n$} \\
\hline 0 & & 7 & II & 38 & 14 & 30 & 34 & 3 \\
\hline I & & 3 & 10 & 1 & 12 & 16 & 23 & 4 \\
\hline 2 & & & 2 & I & 10 & 1 & & \\
\hline Unknown & & & 2 & I & 1 & I & & \\
\hline
\end{tabular}

Abbreviations: ISS, International Staging System; PS, performance status (no data collected for multiple myeloma); ECOG, Eastern Cooperative Oncology Group.

this first year as a need to give priority to cancer treatments over other drugs for less serious illnesses. The number of drugs assessed in the subsequent 2 years is consistent with the findings of other studies, and contrasts with the high number of drugs on the market. ${ }^{18-21}$ According to Puigventós Latorre et al, ${ }^{22}$ this could be because the request, assessment, and approval process limits the number of drugs that can be assessed, so priority is given to those that could offer significant advances. This would also explain the high approval rate.

The high percentage of drugs included with criteria for use in this study also illustrates how the function of the PTC has evolved to perform more innovative tasks, such as establishing conditions for drug use. Further development of the process needs to include monitoring of drug use, drug switching protocols, indirect comparisons, and drawing up protocols or clinical guidelines. ${ }^{23,24}$

With regard to compliance, the highest compliance scores were for bevacizumab and trastuzumab, possibly because they are used in more prevalent cancers (breast, colorectal, and lung cancers $)^{25}$ that incur higher costs, so budgetary protocols are more likely to exist and be adhered to for these cancers.

The top compliance score was for bevacizumab in the treatment of metastatic breast cancer. Interestingly, in 2011, the US Food and Drug Administration ${ }^{26}$ withdrew this indication, which had been approved in 2008 as part of its accelerated approval program, because subsequent studies showed that progression-free survival was lower than initially calculated and with significant adverse effects; therefore, the benefits of treatment no longer outweighed the risks. In 2010, the European Medicines Agency withdrew its indication combined with docetaxel, but kept the combination with paclitaxel and later added the indication for first-line treatment in combination with capecitabine for patients in whom treatment with taxanes or anthracyclines was not considered appropriate. $^{27}$

The average compliance score for cetuximab in patients with colorectal cancer was $62.0 \%$. This relatively low score was because none of the patients met the EGFR expression criterion; this test is no longer performed for this tumor type following reports from various studies that the presence of 


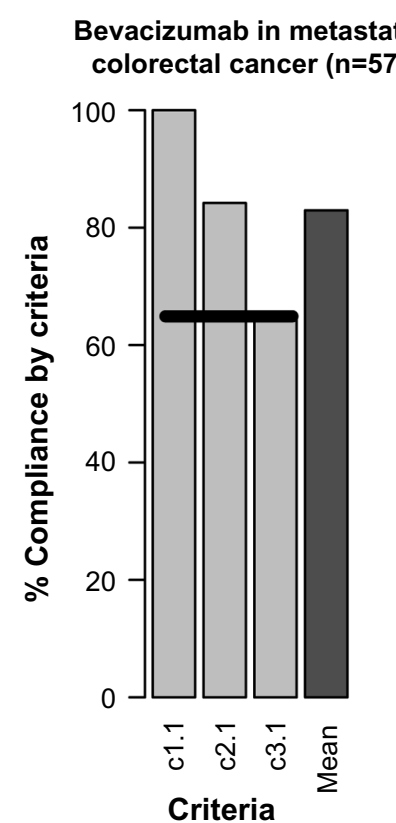

Cetuximab in head and neck cancer $(n=10)$

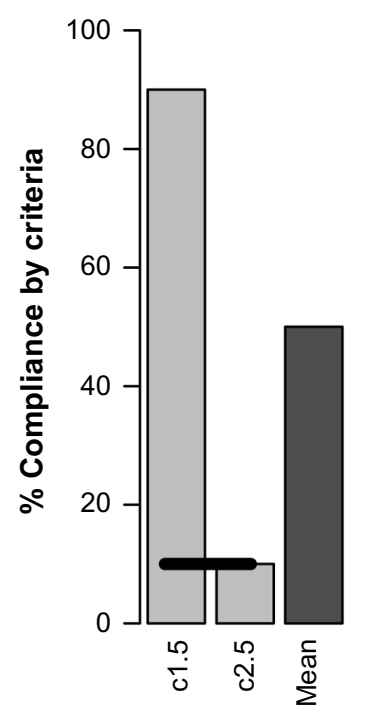

Criteria
Bevacizumab in metastatic breast cancer $(n=7)$

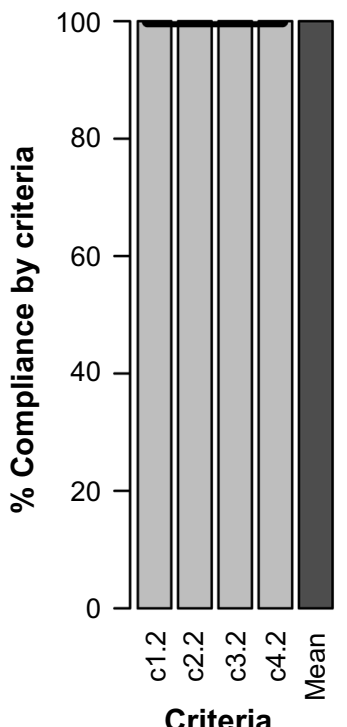

Criteria

Trastuzumab in early breast cancer $(n=41)$

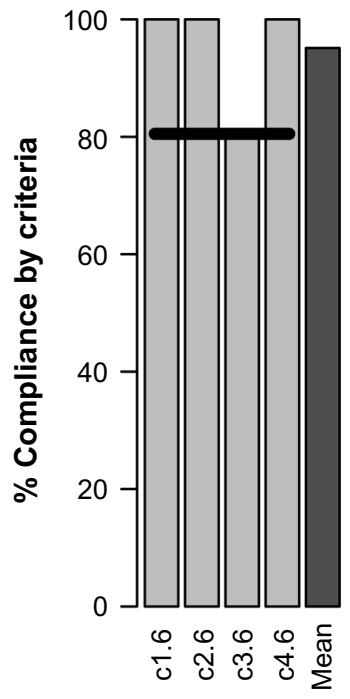

Criteria
Bevacizumab in non-small-cell lung cancer $(n=48)$

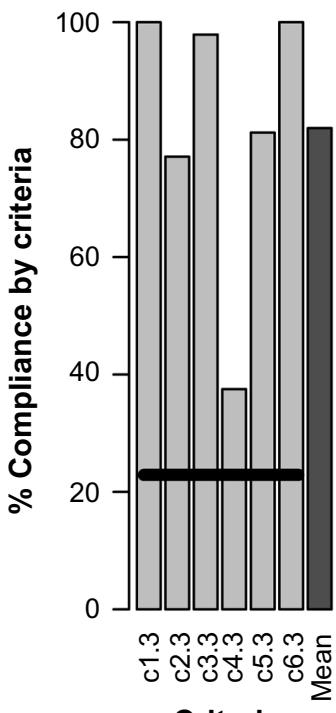

Criteria

\section{Trastuzumab in metastatic breast cancer $(n=37)$}

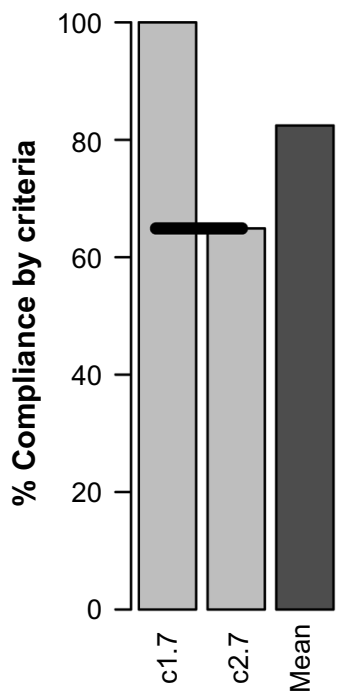

Criteria
Cetuximab in colorectal cancer $(n=25)$

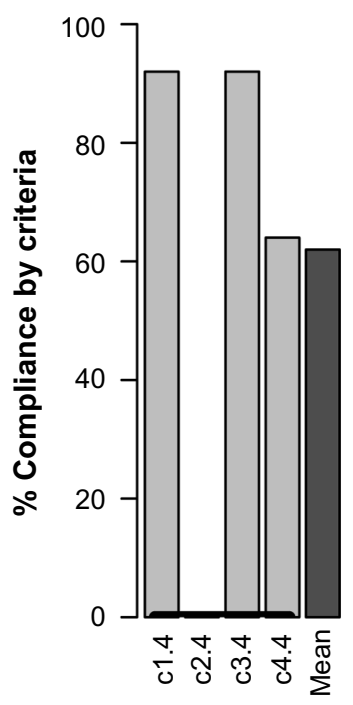

Criteria

Bortezomib in multiple myeloma $(n=62)$

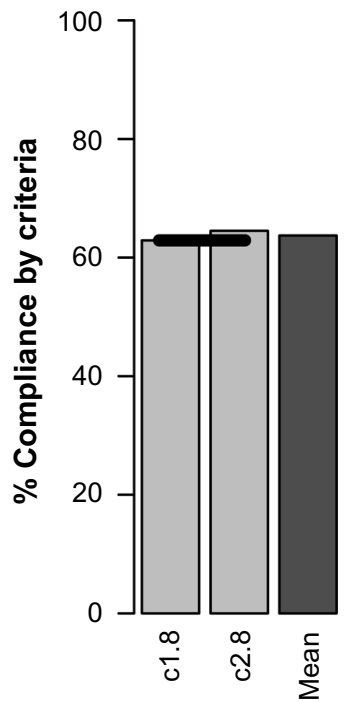

Criteria

Figure I Indicator scores for the degree of compliance of prescriptions for cancer drugs with criteria for use.

Notes: The black horizontal line shows the percentage of patients who fulfilled all the criteria. "Mean" refers to the mean score for patients treated with each drug in each clinical indication based on the scores in compliance with Cabueñes Hospital Pharmacy and Therapeutics Committee criteria.

the EGFR mutation does not determine cetuximab activity. ${ }^{28}$ After the drug was approved by the PTC, the European Medicines Agency ${ }^{29}$ changed the indication to EGFR-positive patients with the wild-type $K R A S$ gene. This is a good example of why PTC criteria need to be regularly reviewed and amended where appropriate. The lowest compliance score was for cetuximab in head and neck cancer (50.0\%), where all but one of the patients could have received cisplatin, but an unapproved regimen (paclitaxel + cetuximab) was used instead. This is important because one of the ways to make cancer treatments more affordable is to monitor and reduce off-label use, which is used sometimes, according to Sullivan et al, ${ }^{30}$ in scenarios where there is little benefit and more toxicity compared with drugs that cost much less. If the compliance results had been assessed as the percentage of patients meeting all criteria defined by the PTC, the result would have been much lower, especially in the case of cetuximab. One of the criteria for use of bortezomib was 
that patients needed to have relapsed or be resistant to at least one treatment. In August 2008, the European Medicines Agency authorized a new indication for previously untreated patients not eligible for high-dose chemotherapy with bone marrow transplant. ${ }^{31}$

The new indications approved by regulatory agencies after drugs are included in formularies show that drugs need to be reassessed by the PTC, and if appropriate, their criteria for use amended. The PTC should also carry out studies on the way in which approved drugs are used, in order to measure the degree of compliance with criteria for use, as recommended in the American Society of Health-System Pharmacists guidelines. ${ }^{32}$

The foremost limitation of the current study is that the results were interpreted retrospectively. A second limitation was the small number of patients with some low-prevalence cancers that could only have been resolved by increasing the length of the study period, as all of the patients treated after a drug was included in the formulary were included in the study. However, the 3-year study period was the maximum length at the time the study began because, as mentioned above, the PTC was inoperative for a year and when it became active again new working guidelines were established. Third, the results are limited because the study was done in one center and with very specific drugs. If the study had been done in another setting with other drugs, the results could have been different, which compromises the external validity of the study.

The Spanish reimbursement process is changing, and the new process intends to rationalize, standardize, and expedite the assessment of new drugs. This study was conducted some years ago, so it would be interesting to do it again to see if the results would be similar nowadays.

\section{Conclusion}

The degree of compliance with criteria for use of cancer drugs is reasonably high. PTCs need to regularly review their criteria for use of individual drugs in light of clinical guidelines and newly approved indications. PTCs also need to continue to evolve and adapt their activities with regard to drug assessment, monitoring, and development of protocols. Further research should be carried out to investigate the clinical and financial benefits of establishing criteria for use as part of the drug selection process.

\section{Acknowledgment}

We would like to thank Gemma Cherry from the University of Liverpool who read and commented on a draft version of this paper.

\section{Disclosure}

The authors declare that they have no conflict of interest in this work.

\section{References}

1. Hartman M, Martin AB, Benson J, Catlin A. National health spending in 2011: overall growth remains low, but some payers and services show signs of acceleration. Health Aff (Millwood). 2013;32(1):87-99.

2. Ramli A, Aljunid SM, Sulong S, Md Yusof FA. National Drug Formulary review of statin therapeutic group using the multiattribute scoring tool. Ther Clin Risk Manag. 2013;9:491-504.

3. Zhang Y, Soumerai SB. Do newer prescription drugs pay for themselves? A reassessment of the evidence. Health Aff (Millwood). 2007;26(3):880-886.

4. [No authors listed]. New drugs and indications in 2012. Sluggish progress, timid measures to protect patients. Prescrire Int. 2013;22(137): 105-107.

5. Directive 2004/27/EC of the European Parliament and the Council of March 31, 2004 amending Directive 2001/83/EC on the Community code relating to medicinal products for human use (Text with EEA relevance), 2004. Official Journal L136, 30/4/2004. 2004;268:34-57. Available from: http://eur-lex.europa. eu/LexUriServ/LexUriServ.do?uri=CELEX:32004L0027:EN:HTM L. Accessed February 15, 2014.

6. Pignatti F, Gravanis I, Herold R, Vamvakas S, Jonsson B, Marty M. The European Medicines Agency: an overview of its mission, responsibilities, and recent initiatives in cancer drug regulation. Clin Cancer Res. 2011;17(16):5220-5225.

7. Soto Alvarez J. [Therapeutic and social usefulness of medicines: how can it be evaluated and quantified?]. Med Clin (Barc). 2009;132(3): 104-105. Spanish.

8. Fullerton DSP, Atherly DS. Formularies, therapeutics, and outcomes: new opportunities. Med Care. 2004;42(Suppl 4):III39-III44.

9. Drummond MF, Mason AR. European perspective on the costs and cost-effectiveness of cancer therapies. J Clin Oncol. 2007;25(2): 191-195.

10. McCabe C, Bergmann L, Bosanquet N, et al. Market and patient access to new oncology products in Europe: a current, multidisciplinary perspective. Ann Oncol. 2009;20(3):403-412.

11. Smith TJ, Hillner BE. Bending the cost curve in cancer care. $N$ Engl $J$ Med. 2011;364(21):2060-2065.

12. Group for Innovation Assessment Standardisation and Research in the Selection of Drugs (GENESIS) of the Spanish Association of Hospital Pharmacy. MADRE Programme. Procedures Manual. PDF 3.0 version, 2005. Available from: http://gruposdetrabajo.sefh.es/genesis/index. php?option $=$ com_content $\&$ view $=$ article $\& i d=11 \&$ Itemid $=13$. Accessed February 15, 2014.

13. García Robredo B, Calleja Hernández MA, Luque Vega MI, Ubago Pérez R, Faus Dáder MJ. [Compliance of prescriptions for chronic obstructive pulmonary disease patients given upon hospital discharge]. Farm Hosp. 2010;34(4):188-193. Spanish.

14. R Core Team. R: A language and environment for statistical computing. R Foundation for Statistical Computing, Vienna, Austria. Available from: http://www.R-project.org/. Accessed February 15, 2014.

15. WHO Collaborating Centre for Drug Statistics Methodology. Guidelines for ATC classification and DDD assignment 2011. Oslo: World Health Organization; 2010. Available from: http://www.whocc.no/filearchive/ publications/2011 guidelines.pdf. Accessed June 25, 2014.

16. Puigventós F, Santos-Ramos B, Ortega A, Durán-García E. Structure and procedures of the pharmacy and therapeutic committees in Spanish hospitals. Pharm World Sci. 2010;32(6):767-775.

17. Ortega Eslava A, Puigventós Latorre F, Santos-Ramos B, Calderon Hernanz B, Vilanova Boltó M. [Classification and variability of drug assessment reports on the GENESIS group (SEFH) webpage]. Farm Hosp. 2011;35(3):140-147. Spanish. 
18. [New Medicines: 2007 Review]. Información Terapeútica del Sistema Nacional de Salud. 2008;32(1):17-25. Available from: http://www. msssi.gob.es/va/biblioPublic/publicaciones/docs/vol32_1NuevosPrin cipiosActivos2007.pdf. Accessed February 15, 2014. Spanish.

19. [New Medicines: 2008 Review]. Información Terapeútica del Sistema Nacional de Salud. 2009;33(1):15-22. Available from: http:// www.msssi.gob.es/va/biblioPublic/publicaciones/recursos_propios/ infMedic/docs/vol33_1ppiosActivos.pdf. Accessed February 15, 2014 Spanish.

20. [New Medicines: 2009 Review]. Información Terapeútica del Sistema Nacional de Salud. 2010;34(1):12-25. Available from: http://www. msssi.gob.es/va/biblioPublic/publicaciones/recursos_propios/infMedic/docs/BoletinVo134n1_12a25.pdf. Accessed February 15, 2014. Spanish.

21. [New Medicines: 2010 Review]. Información Terapeútica del Sistema Nacional de Salud. 2011;35(1):21-31. Available from: http:// www.msssi.gob.es/va/biblioPublic/publicaciones/recursos_propios/ infMedic/docs/vol35_1_Nuevos_PA.pdf. Accessed February 15, 2014. Spanish.

22. Puigventós Latorre F, Santos-Ramos B, Ortega Eslava A, Durán-García ME. [Variability in activity and results from drug assessments by pharmacy and therapeutics committees in Spanish hospitals]. Farm Hosp. 2011;35(6):305-314. Spanish.

23. Durán-García E, Santos-Ramos B, Puigventos-Latorre F, Ortega A. Literature review on the structure and operation of Pharmacy and Therapeutics Committees. Int J Clin Pharm. 2011;33(3):475-483.

24. Hoffmann M. The right drug, but from whose perspective? A framework for analysing the structure and activities of drug and therapeutics committees. Eur J Clin Pharmacol. 2013;69 Suppl 1:79-87.

25. Ferlay J, Shin H-R, Bray F, Forman D, Mathers C, Parkin DM. Estimates of worldwide burden of cancer in 2008: GLOBOCAN 2008. Int $J$ Cancer. 2010;127(12):2893-2917.
26. US Food and Drug Administration. Postmarket Drug Safety Information for Patients and Providers. Avastin (bevacizumab information), 2011. Available from: http:/www.fda.gov/Drugs/DrugSafety/PostmarketDru gSafetyInformationforPatientsandProviders/ucm193900.htm. Accessed February 15, 2014.

27. European Medicines Agency. Changes since initial authorization of medicine. Avastin-H-C-582-II-33: EPAR Assessment Report-Variation. Available from: http://www.ema.europa.eu/docs/en_GB/document library/EPAR_-_Assessment_Report_-_Variation/human/000582/ WC500108311.pdf. Accessed February 15, 2014.

28. Ng K, Zhu AX. Targeting the epidermal growth factor receptor in metastatic colorectal cancer. Crit Rev Oncol Hematol. 2008;65(1): 8-20.

29. European Medicines Agency. Changes since initial authorization of medicine. Erbitux-H-C-558-II-20: EPAR Assessment report variation. Available from: http://www.ema.europa.eu/docs/en_GB/document_ library/EPAR_-_Assessment_Report_-_Variation/human/000558/ WC500029117.pdf. Accessed February 15, 2014.

30. Sullivan R, Peppercorn J, Sikora K, et al. Delivering affordable cancer care in high-income countries. Lancet Oncol. 2011;12(10): 933-980.

31. European Medicines Agency. Changes since initial authorization of medicine. Velcade-H-C-539-II-28: EPAR Assessment Report Variation. Available from: http:/www.ema.europa.eu/docs/en_GB/ document_library/EPAR_-_Assessment_Report_-_Variation/ human/000539/WC500048473.pdf. Accessed February 15, 2014.

32. Tyler LS, Cole SW, May JR, et al. ASHP guidelines on the Pharmacy and Therapeutics Committee and the formulary system. Am J Health Syst Pharm. 2008;65(13):1272-1283.

33. Reuben DB, Mor V, Hiris J. Clinical symptoms and length of survival in patients with terminal cancer. Arch Intern Med. 1988;148(7): 1586-1591.
Therapeutics and Clinical Risk Management

\section{Publish your work in this journal}

Therapeutics and Clinical Risk Management is an international, peerreviewed journal of clinical therapeutics and risk management, focusing on concise rapid reporting of clinical studies in all therapeutic areas, outcomes, safety, and programs for the effective, safe, and sustained use of medicines. This journal is indexed on PubMed Central, CAS,

\section{Dovepress}

EMBase, Scopus and the Elsevier Bibliographic databases. The manuscript management system is completely online and includes a very quick and fair peer-review system, which is all easy to use. Visit http://www.dovepress.com/testimonials.php to read real quotes from published authors. 